\title{
An Introduction to Crisis Reporting: Setting Out
}

James accepted his boss' offer-or rather demand - to report on the catastrophe at the island of San Lorenzo with a sense of responsibility. Not that he naïvely believed that his individual action would matter, locally or globally. Rather, he had made the choice to enjoy the game while sticking to some journalistic principles and ideals that he maintained and even believed in.

Apart from the frozen corpses that were rumored on Twitter, James did not really know what to expect. After all, it was supposed to be his first experience with crisis reporting. He was therefore making a thorough research into anything relevant and, after that, less relevant. While waiting for his flight to San Lorenzo in the departure lounge and scrolling through the web, he eventually chanced on several personal confessions from experienced reporters.

"I never thought I'd get PTSD. I was calm, rational and decisive. I enjoyed being in charge of large editorial teams. I felt I could detach myself from tough situations when needed. (...) The flashbacks, the anxiety, my emotional numbness and poor sleep had long worried my wife, Mary," the editor Dean Yates, who had been working for Reuters for 23 years, wrote in a special report for the news agency (Yates 2016). In a podcast recorded for War College, he expanded upon his current emotional state: "Even crying, for example. One of the problems that I found, I just ... I find it hard to really express my emotions. Because I've been emotionally numb for so many years" (War College 2016). His post-traumatic stress disorder (PTSD) resulted from the long-term stress he

J. Kotišová, Crisis Reporters, Emotions, and Technology, https://doi.org/10.1007/978-3-030-21428-9_1 
had experienced as a reporter, covering, among other things, the tsunami in Indonesia's Aceh province in 2004, the Iraq War between 2003 and 2008 , and the Bali bombings in 2002. In particular, Dean struggled with feelings of guilt after two Middle Eastern colleagues for whom he was responsible were shot dead by a US Apache helicopter. Also, he could not get rid of the images of thousands of corpses he saw while covering the Indonesian tsunami. Every now and then, they popped up in his head. But it was only in 2016 that Dean and his family fully felt the effects. "I had played down the symptoms, denied I had a problem. Five months later I'd be in a psychiatric ward," he wrote at Reuters" website.

In another Reuters story (Joelving 2010), former BBC reporter Chris Cramer, suffering from a similar problem, admitted: "The last thing you wanted to do in those days was to admit to your boss that you kind of lost your nerve. (...) Newsrooms were very macho places, you know." Cramer had been carrying his PTSD since 1980 when he, together with 25 other people, was taken hostage in Teheran by six Iranian gunmen.

“I will be honest, I ... I ... I reached a plane where I couldn't identify the things that were horrific. I couldn't even notice that there were things that were happening around me that were important or significant or that an international audience or Arab audience or anyone should actually see," Rami Jarrah, a Syrian reporter covering the besieged city of Aleppo at the end of 2016, said in an interview with Christiane Amanpour for her CNN show (Amanpour 2016). "You mean because you got numb to it, Rami?" Christiane asked for clarification. Rami replied, redirecting viewers' attention back to the people of Aleppo: "The people inside are totally numb. They don't see what is happening around them anymore." Rami had the "advantage" that he, as a domestic reporter, could cover the airstrikes and bombings by Assad and the Russians on the spot in the increasingly dangerous areas, since the regime had mostly stopped giving out press credentials to international media professionals.

However, not even distant reporting on Aleppo was a walk in the park. Kareem Shaheen, a Middle East reporter for The Guardian, based in Beirut, in an article called "Covering the last days of Aleppo: Even from afar, the heart breaks" (Shaheen 2016), ruminated: "how do you maintain a dispassionate distance when you've been, for three months, looking at the bodies of the children those doctors had to treat? Or stayed up through the night to listen in to the palpable horror in the voices of those living under the bombs? How could you not pray for their safety, and ask them to take care of themselves?" 
There was a unique and deeply intimate experience behind each of the quotations. At the same time, they were all journalists' publicly shared narratives about the personal consequences of covering various crisis situations - post-traumatic stress disorder, emotional numbness, feelings of guilt, denial of emotional problems, physical risks, loss of insightfulness, neglecting one's own emotional health when face to face with the tragedies of other people, trauma caused by witnessing distant suffering, confrontation with the paradoxes of passion and detachment, and acting and observing. Obviously, the journalists' own stories accounted primarily for the emotional experiences that ultimately pervade their social and professional lives. All the stories, placing the journalists themselves at the center of the narrative, were also cases of extreme, escalated visibility of journalists' own emotions being reported in the news. It was one of the few occasions when James saw that journalists were the story, not just writing it.

After a short moment of empathy, he conceived a distaste for the journalists. Like some of his colleagues-Bob, Diego, but mainly Farrukh-he actually disliked when the reporters brought themselves into focus, thus overshadowing the "real" victims of crises.

Yet, based not only on what he had just read but also on his past conversations with his colleagues and friends who often, usually late and over a glass, brought up "how it felt" when they were covering this or that crisis, he had to acknowledge that the reporters' own mental well-being at work might have been a problem - both in itself for them and in affecting their reporting.

The emotional aspects of crisis reporting have been also a constantly under-researched and under-theorized issue within media and journalism studies (Beckett and Deuze 2016; Peters 2011). Apart from a few recent papers directly focused on journalists' emotional labor (e.g. Hopper and Huxford 2015), media and journalism research, including the orthodox works on crisis reporting (e.g. Cottle 2009), have not had much to say about journalists' emotions. The vast majority of research on the media in crises focuses on the coverage of crisis situations. Those studies that address journalists' practices and professionalism mention emotions only in the margins. Many-most often quantitative, and frequently normative-studies of crisis reporting deal with general framing, sourcing and gatekeeping strategies, or representation of actors in the crises (e.g. BenYehuda et al. 2013; Falkheimer and Olsson 2015; Van Der Meer et al. 2016; Van Leuven et al. 2013). Second, leaving aside the relatively few works on ethnographic, new, or literary journalism that focus directly on 
journalists' personal engagement, immersion, and related genres (e.g. Pauly 2014), most studies addressing journalists' practices and professional culture still mention emotions only in the margins, stressing the complex and ambivalent relation of personal attachment/detachment to objectivity, truth, and professionalism (Andén-Papadopoulos and Pantti 2013; Tumber 2006; cf. Glück 2016). Journalists' emotions and their effect on reporting remain black boxes, elephants in the room of journalism studies. The low interest in journalists' emotions within existing research on the media is particularly noticeable when compared to the extensive research dedicated to the emotionality of other professionals - such as doctors and caretakers-within the realm of the sociology of work (e.g. Hayward and Tuckey 2011). Third, the emotional risks and well-being of journalists, mainly those who are responsible for conveying traumatic events to the public, have come under scrutiny rather from think tanks, research organizations, and professional associations such as the Dart Centre for Journalism and Trauma (DCJT) and the International News Safety Institute (INSI). The researchers attached to these institutes agree that covering crises and repeated exposure to drastic user-generated content can bring about serious psychological effects: post-traumatic stress disorder, headache, and early waking syndrome (Dubberley et al. 2015; Hight and Smyth 2003; Sambrook 2016). But since their aim is to offer evidence-based recommendations and to design individual training programs for those covering war zones, terrorism, or natural disasters, they do not attempt to put the findings into theoretical and social context. Thus, although all these research streams concern crisis reporters' emotional culture, directly or indirectly, they either fail to open the black box, or stress the structural and normative aspects of newswork at the expense of journalists' individually lived experiences, or fail to provide tools that would enable contextualized understanding and critique.

The media are limited neither to words and representations nor to sets of values and principles; they are complexes of persons, things such as technological devices and architecture, texts, meanings, and power relations (Hansen 2006; Lievrouw 2014; Packer and Crofts Wiley 2012). In particular, there are journalists' thoughts and practices—strategic actions, their unintended consequences, more or less conscious choices of words, use of practical devices - that lead to the construction of frames and other (desired) effects that, taken together, constitute media content and foreshadow its social and political biography. Thus, it is important to examine the influences of these various factors on the reporting of crises (Neumann 
and Fahmy 2016). In a crisis, it is profoundly important to ask how journalists are working within the media organization, to study their routines in a broad sense, all the more so that recent changes in media logicthe increasing importance of interpretation and speculation at the expense of description-give the journalists a more prominent position in the news (Nord and Strömbäck 2006). Since journalists' emotions are part of the media complexes of people, devices and other material artifacts, texts, and power relations, they are also vital for the processes of crisis reporting and their outcomes. As Charlie Beckett and Mark Deuze write, especially with digital, networked journalism, "emotion is becoming a much more important dynamic in how news is produced and consumed" (Beckett and Deuze 2016: 2). Likewise, Karin Wahl-Jorgensen (2016) sees emotion as a central force shaping the news agenda and enabling new forms of engagement among audience members. Finally, Mervi Pantti (2010) speaks about the normalness of emotion in television news and identifies a shift in journalists' perceptions of the use of emotion in favor of its greater acceptance.

James glanced up to the ceiling; one of the light bulbs was flickering. Then, his gaze, usually searching and radiant with interest but today rather groggy, slid down to an empty massage chair directly opposite him. The bleak space of the early morning hall, albeit situated in the heart of the "First World," was already stirring up melancholy.

Studying journalists' emotions is particularly essential in the field of research on crisis reporting. Journalists' emotions lie precisely at the core of the paradox of the traditional journalistic commitment to objectivity/detachment and witnessing other people's suffering (AndénPapadopoulos and Pantti 2013; Richards and Rees 2011). In crisis reporting, more than in other journalistic fields, journalists' position between an involved actor and detached observer, entailing the dichotomies of engaged/non-participating, active/passive, empathic/dispassionate, or close/distant, becomes more palpable and pressing (e.g. Tumber 2011). Moreover, journalists and media easily become central to the politics of conflicts (e.g. Altheide 2004; Hoskins and O'Loughlin 2010), which imparts specific kind of importance to crisis reporters' practices, thoughts, and feelings.

How should (and can) I, James thought, live through, let in, sympathize with, work with, let out, and use for the sake of the story people's tragedies that constitute crises? (How) can I stay detached, neutral, emotionally disinterested, when I actually am there? And do I want to? 
He looked at the departure board. The flight to San Lorenzo was 35 minutes late, so he still had almost two hours until boarding. Although he was one of those who felt more comfortable on the move, armed only with independence, and who showed little interest in the steady, calm, and homely kind of happiness, he was never able to focus on work at airportsthese boundary zones, these no man's lands. Ruminating about the problem of journalists' emotions, and immersed in the questions it raised, James' thoughts kept wandering to his chaotic memories of colleagues' stories, his own college years, and his newsroom experience.

Intermingling with, at times following yet often going well beyond James' thoughts, this study seeks to enhance the existing research on the interrelations between communication media and crisis situations by focusing on crisis reporters'-James' colleagues'-emotional culture. In particular, it deals with their emotional experience at work and how it is articulated by and in their professional practices. It addresses three main research questions: What does "crisis" in "crisis reporting" mean? What is the emotional experience of crisis reporters? How does the newsmaking technology articulate journalists' emotional experience of crisis?

Each of the questions gives rise to further sub-questions, such as the following: How do reporters perceive the place and role of emotions in their news/reports? What coping mechanisms and practices do they use? How is their psychological well-being addressed by media organizations?

\section{StATE OF THE ART}

\section{Vague Ideas of Crisis, Emotions, Technology}

James, having graduated a few years before and being rather more excited about any and all knowledge than focusing on crisis reporting, had only a vague idea about the basic, sensitizing concepts that would guide this study (Blumer 1954; Bowen 2006): crisis, emotions, and technology.

He knew the original medical (and legal and theological) meaning of the word "crisis" (Vincze 2014; see the chapter "Defining a Crisis: Boarding"). But the word could be used and was being used in ( $\mathrm{m}$ )any other context(s). He was also aware that "crisis reporting" had long ago become a classic field of both journalism and journalism research. Media scholars define the catchphrase "crisis" as a sudden, unpredictable, or challenging event that may pose a danger to society and create strong uncertainty, time pressure, and confusion that challenge journalistic 
practices and standards (Van Der Meer et al. 2016; Vincze 2014), and contrast "crisis" with "normal times" (McDonald and Lawrence 2004).

James experienced emotions as "thoughts somehow 'felt' in flushes, pulses, 'movements' of our livers, minds, hearts, stomachs, skin, (...) embodied thoughts, thoughts seeped with the apprehension that 'I am involved" (Rosaldo 1984: 143). As "embodied thoughts," emotions are not only individually biological/psychological but also to a large extent culturally determined, defined, and shaped practices of feeling and thinking, lying at the intersection of political, biological, and social bodies of human beings (Scheer 2012; Scheper-Hughes and Lock 1987). Correspondingly, "emotional experience" entails both automatic responses and active doings: emotions can be mobilized, named, communicated, and regulated (see Hochschild 1983; Illouz 2007; Scheer 2012).

The third concept, technology, was initially supposed to conceptualize the link between James as a human being with his bodily sensations subjected to outside forces, and the situation of crisis that he was just about to enter-things with which he would be constitutively entangled (Orlikowski 2007) while covering a crisis situation. However, conceiving technologies as mere devices would be inaccurate, because the fact that James had a voice recorder and a camera in his backpack was indistinguishable from his position as a journalistic semi-rookie working for a particular media company. The sum of things, power vectors, processes, and signs that linked James the journalist to his context, appeared to be best conceptualized very broadly as a complex of technologies of production, technologies of sign systems, technologies of power, and technologies of the self (Foucault 1988). This "technology" would encompass material, immaterial, organic, and inorganic conditions and means of news production; the sign systems employed throughout newswork and especially for making news; embodied power relations, for example expectations from management and codified professional principles; and the ways of handling one's self, including bodily emotions (see Du Gay 1996; Greene 2012; Hay 2012; Packer and Crofts Wiley 2012).

James felt restless. Too much time for doing nothing, too little time for starting to do something. From habit, he pulled out an old issue of Le Soir and started aimlessly leafing through its pages.

Although, for now, the sensitizing concepts seem rather abstract, in between them there appear three concrete streams of existing research that interlink the former, each of them in one way or another related to emotions in crisis reporting (Image 1.1). 


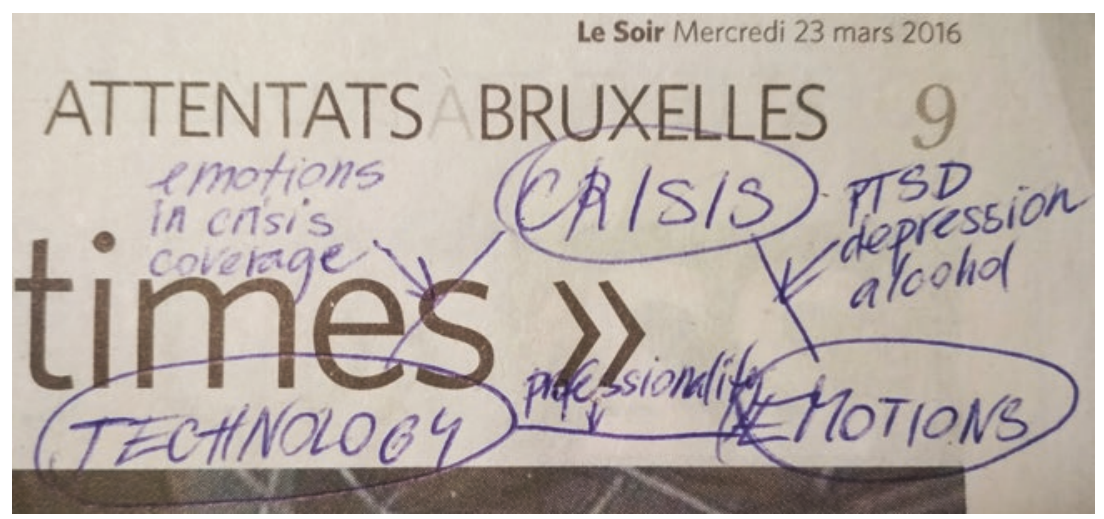

Image 1.1 The concepts of crisis, emotions, and technology and the current streams of research on media and crisis. Drawing (on the issue of Le Soir from 23 March 2016) by the author

The knowledge that had emerged within the three relevant streams of research, namely studies of crisis coverage; conceptualizations of emotionality, objectivity, and professionalism; and applied research of reporters' emotions, is a useful starting point. Although they put one-sided emphasis on media content or, contrarily, on principles, norms, and values, or let the description float, all the current research streams are mutually interconnected by the very practices and emotions of journalists. Moreover, they emerge at the gap sites between, and at the margins of, the concepts of crisis, technology, and emotions.

First, the research on (emotions in) crisis coverage attempts to grasp how the technology of newsmaking enters, but also constitutes a crisis event, and how the latter challenges the technology. (While focusing on outcomes of reporting, however, it cannot take into account journalists' "raw" emotions.) Second, the work on emotionality and objectivity in journalistic professionalism investigates the place and the role of emotions within the newsmaking machine. (But with a few exceptions, it does not account for a possible change in the traditional, emotionally detached professionalism that a crisis event can bring about.) Third, the applied research on journalists' mental difficulties well describes the entanglement of human beings' emotions and crisis events (but fails to establish a theoretically solid and unequivocal relation with the complex technological context of crisis reporting). 


\section{Emotions in Crisis Coverage}

James got to the last page of Le Soir. Annoyed by the monotone frustration it radiated, he put it away.

Given the importance of the news values on negativity or "bad news" (Galtung and Ruge 1965; Harcup and O'Neill 2001), it is not surprising that crisis reports and events in general attract the public, media workers, and media researchers. The interrelations of media messages and wars, conflicts, terror attacks, natural disasters, environmental catastrophes, economic depressions, technological breakdowns, transportation disasters, and so on have been thematized by major media scholars (e.g. Allan et al. 2000; Cottle 2009; Tumber 2006; Zelizer and Allan 2011). Much of the research and theory stresses the shift toward a milieu in which the media and the news become involved in decision-making processes, and thus central to the politics of conflicts (Altheide 2004; Hjarvard 2008; Hoskins and O'Loughlin, 2010). The "CNN effect," referring to the process by which global broadcasting companies, by transmitting scenes of human suffering, prompt shifts in (trans)national foreign policies and can even stimulate humanitarian interventions backed by military forces (Cottle 2009), has also been thoroughly investigated. To mention just a few examples, Hemda Ben-Yehuda et al. (2013: 72), Toni G. L. A. Van Der Meer et al. (2016), and Rico Neumann and Shahira Fahmy (2016) have argued that by making crisis news, journalists may affect escalation processes. According to the researchers, framing transforms events through filtering and reflecting images of reality in world politics, so that, for example, chasing after ratings may bring about a rise in tensions or create panic. In short, the news media not only communicate crises to the public but also discursively and, at times, tangibly constitute them (see Van Loon 2002).

It is not unjustified, then, that the vast majority of research on the media and various kinds of crisis focuses on media coverage of the latter. The classic works on crisis reporting such as Daniel C. Hallin's The "Uncensored War": The media in Vietnam (1986) and Simon Cottle's Global Crisis Reporting: Journalism in the Global Age (2009) are based primarily on analysis of media content and media construction of crises, which provides background for speculating about the effect of media content in national or global societies.

Even James had read Hallin and Cottle-nearly all journalism students did peek into this hall of fame. 
Hallin describes in great detail the history of reporting on the Vietnam War, criticizes what TV news and the papers had to say about it, while showing the apparently growing prominence of the media. He not only investigates and engagingly depicts the representation of different phases of the war, and of its main protagonists and antagonists (good American "round-eyes" and the bad guys from the Viet Cong) but also traces the mutual effects of television/press coverage of the war and military/political decisions. Indeed, one of the most important and interesting motives of his book is (the limits of) television's role in the collapse of consensus within American society. However, any claims related to this issue inevitably remain hypothetical: studying media effects is epistemologically deeply problematic, such that the debate whether empirical research can show that specific messages transmitted by television have any specific effects on their audiences remains unresolved (e.g. Livingstone 1996), and research empirically based primarily on analysis of media content can only speculate about media effects. Yet, Hallin very convincingly shows the ambivalence inherent to (American) journalism: the paradox that the great tales of journalistic heroism are based on reporters' feelings that they need to question the people in power and that their work is grounded in political independence, while the media have become integrated into the process of government. What a pity that the book, drawing also on interviews with journalists involved in the war, does not have much to say about the anthropological—or rather human-dimension of American journalism during the war, as if journalists were standardized executors of certain journalistic principles. The author only hints at their (emotional) experience, simultaneously acknowledging and relativizing its importance by stressing the US domestic political context of the war:

Surely it made a difference, for instance, that many journalists were shocked both by the brutality of the war and by the gap between what they were told by top officials and what they saw and heard in the field, and were free to report all this. But it is also clear that the administration's problems with the 'fourth branch of government' resulted in large part from political divisions at home. (Hallin 1986: 213)

In short, Hallin has very little to say about how journalists themselves thought about what they did.

By comparison, Cottle does not focus on an individual crisis, but explores and theorizes processes of social construction in the mediation of 
various global crises. In other words, he looks into how global crises become defined, deliberated, and sensationalized - or denied, hidden, forgotten by the world's news media. While addressing "the media's role within globalization's dark side" and "how media feature within and frame particular global crises" (Cottle 2009: 26), he demonstrates how some of journalism's principles, for example, news values, fuel and shape media interest in crises of a specific scope, duration, and geographic context, and even touches upon the emotionality of reporting. In particular, while discussing the role of the media in natural disasters, the author shows how the events become ritualized and subjected to the rhetoric of national collectivity and morality. Like Hallin, Cottle deals primarily with crisis coverage, its role among audiences, and its political context, in the process rendering individual journalists invisible. In his book, "global journalism" or "foreign correspondence" is mostly approached as institutions, depersonalized systems of practices and exercises. Neither of the authors really looks inside journalism.

Other orthodox authors turn even more outward. For example, Robert M. Entman, together with his colleagues, studies connections between frame competition and political conflict, and identifies the weak relationship between the frames dominating the news and the facts on the ground that are essential for policymaking (Entman et al. 2009; Knüpfer and Entman 2018).

Thus, all these authors analyze media content and speculate about its effects in political contexts. None of them, however, enters the backstage of crisis reporting by taking into account journalists' experiences and perspectives. (At the same time, they all imply that how journalists experience a certain crisis is vital for what the coverage looks like, and thus how the public perceives the crisis, and thus how the coverage helps to shape globalized emotions and cosmopolitan pity, and thus bring into being people's sense of belonging to the rest of the world and their willingness to act.)

The same applies to many other studies of crisis reporting that deal not only with framing, but also with sourcing, gatekeeping strategies, and representation of perpetrators. The studies depict crisis coverage as generally less objective and factual (Nord and Strömbäck, 2006; Olsson and Nord 2015), but also less interpretive than political news (Olsson and Nord 2015); as more biased, relying heavily on official political and police sources (Falkheimer and Olsson 2015; Van Leuven et al. 2013), delayed in comparison to social media (Pang 2013); and as emotional. For example, Ian McDonald and Regina Lawrence in their research of television 
news after September 2011 noticed that the coverage of the terrorist attack was significantly emotional; in early September 11 coverage, emotional content even outweighed informational content $(\mathrm{McD}$ onald and Lawrence 2004; see also Zelizer and Allan 2011). Thus, crisis coverage is considered to be of lower quality (Olsson and Nord 2015), even thoughgiven its centrality to the politics of conflicts-the professional incentives to produce the best possible news may be higher than in "normal times" (McDonald and Lawrence 2004). In line with the focus of the researchers on media coverage and with the tendency to investigate connections of media coverage and political decisions, diverse examples of "failures" of media performance are often criticized without looking into journalism: at journalists, their practices, and specific media organizations (e.g. Bennett et al. 2007).

Nevertheless, media coverage of crises is not uniform (Ben-Yehuda et al. 2013; Cottle 2009), as "crisis" is not a seamless phenomenon. There are diverse types of crises of different origins, natures, duration, and newness, that, in turn, have varied relations to media practices (Coombs 2010; Nord and Strömbäck 2003; Sellnow and Seeger 2013). Lars Nord and Jesper Strömbäck (2003) distinguish four types of crises based on their predictability (surprising character) and newness (repetition), that is, their supposed relation to media practices: "new and surprising events," "new but expected events," "surprising events that have happened before," and "expected events that have happened before" (type I-IV, Nord and Strömbäck 2003: 71).

Although these were rather ideal-typical events, James doubted there can still be something new and surprising or, conversely, a completely calculable situation. Within current geopolitical realities, "new and surprising events" and "expected events that have happened before" are becoming less relevant. On one hand, after $9 / 11$, it would be hard to come up with something less conceivable (Falkheimer and Olsson 2015); on the other hand, long-term crises - such as the hybrid war in Ukraine-take a form which is for various reasons new, and thus pose new challenges to reporters (Hoskins and O'Loughlin 2010). The two remaining types of situations, "new but expected events" and "surprising events that have happened before," were more conceivable. For example, the so-called refugee crisis (James did not like the term "crisis" but yielded to the common usage, as in many other cases) was said to be unprecedented, but could have been expected. In contrast, terrorist attacks in nearby European 
cities such as Paris, Brussels, and Berlin were always shocking but had happened before.

Journalists' practices are vital for how reports and news look and, in turn, are shaped not only by the predictability and newness of the crisis but also by journalists' emotional experience (Beckett and Deuze 2016). It is therefore surprising that emotional aspects of crisis reporting have been largely overlooked by media scholars studying crisis reporting.

A non-white man of James' age arguing with a security guard who was just trying to undress him behind the metal detectors caught James' eyes. James yawned, got up, stretched like a big beast of prey, and strolled away to find another place to sit.

\section{Objections to Objectivity: Emotionality and Professionalism}

Glancing at a newspaper rack by a tobacco shop, he thought of the newsmaking machine beyond it. Behind each piece of news, there was at least one professional who had directly or indirectly lived the story through.

Some researchers mention that the disruptive nature of crisis poses substantial professional problems for journalists (Falkheimer and Olsson 2015); certain kinds of events even seem to shake the foundations of what it means to be a journalist (Zelizer and Allan 2011). This section thus looks at crisis reporters' emotions from a perspective that corresponds with the second research stream. What place do emotions have in the practices and outcomes of crisis newsmaking and in journalists' professional ideology?

The traditional version of journalists' professional ideology, ${ }^{1}$ that is, a collection of shared but continuously challenged strategies and values guiding journalists' construction of their expertise and authority (AndénPapadopoulos and Pantti 2013: 962), includes the commitment to objectivity. Objectivity - understood as detachment, impartiality, fairness, or professional distance (Deuze 2005)—remains a cornerstone of journalists' professional self-perception, an assumed source of their authority and a privileged signifier of "good journalism” (e.g. Carpentier and Trioen 2010;

\footnotetext{
${ }^{1}$ The study takes into account only the relatively current (post-World War II [WWII]) thinking of journalism, which is most relevant for today's media research and journalism practice, not least because it has been tightly linked to journalism's monitorial role within democratic societies. However, as Christians et al. (2009) show, its normative character goes back to Plato and Aristotle.
} 
Schudson 2001). Together with some other norms and values such as autonomy and public service, objectivity represents the core normative and ethical aspect of professionalism (Andén-Papadopoulos and Pantti 2013; Deuze 2005); some scholars even argue that the objectivity norm is central to the constitution of the journalistic field and works as a privileged signifier of "good journalism" (Carpentier and Trioen 2010; Vos 2011). According to Michael Schudson (2001: 149), "the objectivity norm guides journalists to separate facts from values and to report only the facts. Objective reporting is supposed to be cool, rather than emotional, in tone." Correspondingly, the procedural notion of objectivity, that is, objectivity understood as a kind of performance and a set of practices (Blaagaard 2013; Carpentier and Trioen 2010), leads journalists to give voice to each side of a political controversy and report news in a factual, non-interpretive, "rational" style without commenting on it, distorting it, or shaping its formulation (Peters 2011; Schudson 2001), not to mention not being overwhelmed and paralyzed by their feelings. "Normally, journalists don't get struck by events. They report when events strike others. And it is this basic immunity from action that makes the whole regime of neutrality, objectivity, and detachment even thinkable, let alone practical for journalists," Jay Rosen (2011: 36) writes, while persuasively illustrating that on September 11, such a regime was unimaginable for New York reporters.

James' phone was ringing. Fred.

"Yes?" James answered. His voice sounded exceptionally husky this morning.

" $2 \mathrm{k}$ bits, man," his foreign editor announced rather theatrically.

Rather than keeping James updated on the number of casualties, he wanted to check if everything was alright. After all, it was James' first big journey for such a "holy-shit story" (Romano 1986 in Olsson and Nord 2015: 344), and Fred was a good manager. He even looked like and had the manners of a good manager, which at times humorously contrasted with all the hues of slight untidiness yet nobility of the intellectuals that he managed.

James had seen the number on Twitter. "I see. Thanks," he hung up and checked the piece of information once again with another sourceone of those news agencies and large media companies that, as he was taught, was reliable enough.

Crisis reporting is a field in which disruptions to the professional ideology become clearly visible, as the key journalistic values of objectivity, 
impartiality, and detachment are constantly challenged (Olsson and Nord 2015). Journalists involved in crisis reporting face and need to deal with the paradox that they are supposed to keep in mind the traditional normative defining features of journalism while witnessing other people's suffering and tragedies, such that they may experience tension between being an involved actor and being a fly on the wall (Andén-Papadopoulos and Pantti 2013; Richards and Rees 2011). This difficult position, together with the extraordinary circumstances faced by the news organizations, might be the reasons why crisis coverage is often evaluated by media researchers as lesser quality reporting (Falkheimer and Olsson 2015; McDonald and Lawrence 2004; see also the previous section "Emotions in Crisis Coverage"). ${ }^{2}$

The paradox of detachment/involvement (see Elias 1956) that makes crisis reporting more difficult than other journalistic fields is tightly interconnected with the ambivalence of the role of emotions (not only) in crisis reporting. Do emotions emerging from my personal experience, James thought, contaminate objectivity? Or are they an inevitable ingredient of truthful experience, information, and accounts? The journalistic professional discourse faces a profound rupture between normative and descriptive definitions of the role and place of emotions. According to Barry Richards and Gavin Rees, the belief that emotion contaminates objectivity prevails in the journalistic discourse: "Professional norms of detached objectivity are set against journalists' own awareness that they are emotionally affected by the situations they report on, and against their empathy for the individuals involved in the story" (Richards and Rees 2011: 864). However, even the hard, objective, "just the facts" journalism is not unemotional; emotionality is profoundly constitutive of journalistic narratives (Peters 2011; Wahl-Jorgensen 2013; see later in the chapter).

James was cool enough, but he considered any attempt to separate facts from interpretation or his own opinions in a text a losing battle. Also, he found the mainstream sorting of journalistic genres into the more and the less emotional to be ridiculous, obsolete, and annoying.

Likewise, journalism and journalism studies, similarly to other disciplines, have seen an "affective turn" (Richards and Rees 2011). Not only

\footnotetext{
${ }^{2}$ Moreover, media workers have been confronted with multiple interpretations of objectivity related to new media technologies (Deuze 2005); in particular, the traditional commitment to objectivity has been challenged by entanglements with citizen journalism (Andén-Papadopoulos and Pantti 2013; Blaagaard 2013; Thorsen 2008).
} 
have media scholars started to pay attention to the fact that media is an emotionally charged environment and to suggest that personal, affective, and emotional engagement with newswork needs to be considered carefully. Also, students of journalism and media professionals have redefined the classic idea of journalistic objectivity and news itself (Beckett and Deuze 2016). Not that the news has become more emotional; rather, the acceptability of involvement has become more explicit and diverse emotional styles have emerged (Peters 2011).

Considering the contemporary forms of journalism (Christians et al. 2009), especially since the 1960s, the newly emerging trends in journalism such as ethnographic, new, or literary approaches have been advocating the acknowledgment of reporters' emotions as a legitimate part of reports (e.g. Pauly 2014), which resulted in merging the genres of "soft" and "hard" news. In the theory of journalism, (feminist) media scholars have argued that, contrary to the professional "mythology" surrounding traditional journalism, subjectivity and its various manifestations do not contradict objectivity. Both the values are constitutive and necessary elements of journalists' professional identity (Van Zoonen 1998). James knew that some of his colleagues appreciated the trend. In practice, however, very few were really going against the tide.

Furthermore, these shifts have not diminished the demanding nature of the double existence of journalists as involved actors and flies on the wall that requires them to keep their distance. "You cannot be swept away completely by your emotion," as Lotte, one of James' colleagues, said. As K. Megan Hopper and John E. Huxford (2015) in their study of newspaper journalists' engagement in emotional labor put it, journalists advisedly make the distinction between "eye" (i.e. the perspective of a detached observer) and "I" (subjective opinions of the individual reporter). The extent of one's emotional engagement must be carefully monitored-both on the input and on the output. Howard Tumber (2006) gives the example of the Balkan conflict, in which media including the $B B C$ were harshly criticized for acting merely as transmission vehicles. At the same time, depicting the emotional face of war was condemned for opening the door to imprecision and moralizing. Analyzing Pulitzer Prize-winning stories, Karin Wahl-Jorgensen speaks about a "strategic ritual of emotionality" and suggests that "there is an institutionalized and systematic practice of journalists narrating and infusing their reporting with emotion" (WahlJorgensen 2013: 130). The ritual, Wahl-Jorgensen writes, operates alongside the analogous strategic ritual of objectivity. Nevertheless, rather 
than expressing their own emotions, journalists "outsource," police, and discipline the emotional expression. Kari Andén-Papadopoulos and Mervi Pantti (2013) consider the skill to mediate and mitigate suffering in the form of meaningful compositions as one of the key differences between professional and citizen journalists; likewise, Chris Peters (2011) believes that emotion management (Hochschild 1983) is one of the crucial foundations of the job. Following Peter Stearns (1994), Peters (2011: 303) describes the emotional style of a trusted journalist as "American Cool": "To be 'cool' is not to be emotionless, nor is it to be unfeeling. Rather, this emotional posture demands finding the right balance of disengagement and nonchalance, without appearing disinterested." This implies that the right emotional posture can and must be crafted (Hochschild 1983; Illouz 2007).

\section{Journalists' Emotional Labor and Trauma}

Indeed, James recalled conversations with his colleagues regarding their emotional paths from idealistic, enthusiastic college students to tough, hardened old hands. "When you live in it, you realize that the only rescue is cynicism," Kryštof, one of his former colleagues from Czech Television, who was only a few years older than James, told him.

Being seated closer to his gate, James started scrolling through the web again, and chanced into a few studies of reporters' emotionality carried out by think tanks, research centers, and professional associations such as the Eyewitness Media Hub, the Dart Centre for Journalism and Trauma, and the International News Safety Institute.

Taken together, the literature turned out to be about diverse types of trauma. Before James lost interest in the studies, he managed to learn that "Professionals who work with eyewitness media watch disturbing footage from war zones, natural and manmade disasters and accidents over and over again to verify its veracity and to edit out images that are deemed too extreme for viewing by the general public" (Dubberley et al. 2015: 4). "Reporters, editors, photojournalists and news crews are involved in the coverage of many tragedies during their lifetimes. They range from wars to terrorist attacks to aeroplane crashes to natural disasters to fires to murders. All having victims. All affecting their communities. All creating lasting memories" (Hight and Smyth 2003: 2). James was among the 52 percent of journalists who view distressing user-generated content several times a week; on the other hand, he still wasn't able to say whether or not 
it had, similarly as for 40 percent of his colleagues, ${ }^{3}$ a negative impact on his personal life. Nightmares, feelings of isolation, a negative view of the world, flashbacks (Dubberley et al. 2015; see also Høiby and Ottosen 2015; Marthoz 2017)? Did I ever have a positive view of the world? James was not sure. A few eyewitness graphic images from San Lorenzo that he saw on Twitter a while ago came unbidden to his mind (Image 1.2). And then older memories and sounds. ${ }^{4}$

The relatively few previous studies on crisis reporters' emotions showed that the practice of covering crises and conflicts is indeed significantly interwoven with journalists' emotional experience and mental well-being. The prevalence of PTSD among journalists is higher than among the general population (Aoki et al. 2012). In particular, higher rates of mental ill-health have been found in the subcategories of war reporters, journalists covering conflicts and crises, and those working with user-generated

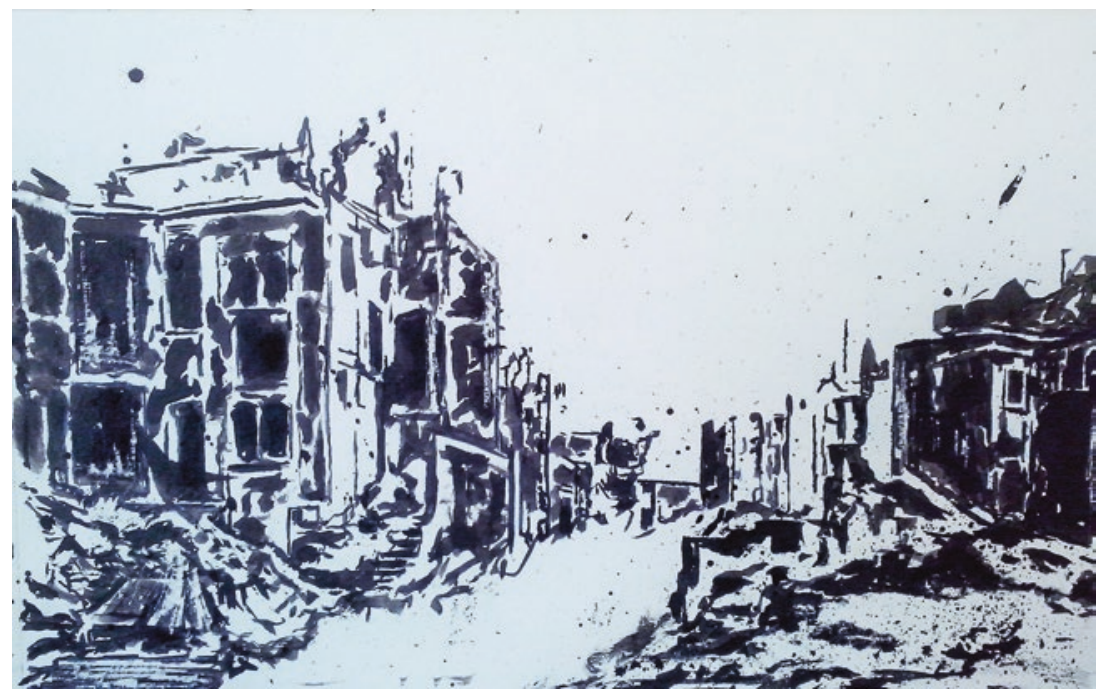

Image 1.2 A frozen city. Drawing by Peter Van Goethem, 2017. Courtesy of the artist

${ }^{3}$ These 40 percent refer to the general sample, comprising not only journalists but also human rights and humanitarian professionals.

${ }^{4}$ Sound is one of the most distressing elements of eyewitness media (Dubberley et al. $2015)$. 
content that often includes disturbing images (Feinstein et al. 2015; Reinardy 2011; Richards and Rees 2011). Frequent, repeated, cumulative, and unexpected exposure to violent images, be it direct or indirect, is emotionally distressing to such an extent that it purportedly determines depression, anxiety, post-traumatic stress disorder, alcohol abuse, headaches, and early waking syndrome (Dubberley et al. 2015; Feinstein et al. 2015).

According to a survey conducted by researchers from the International News Safety Institute, the mental health of journalists is increasingly at risk (Clifford 2016). Indeed, symptoms of PTSD are evident not only among on-the-spot reporters, but also among the staff working on a frontline which is no longer geographic but digital (Clifford 2016; Dubberley et al. 2015 ). One of the reasons might be that post-traumatic reactions are not determined solely by being on the scene and directly witnessing human suffering, but are also related to increased exposure to dilemmas, feelings of guilt, or tension between journalists' beliefs about professionalism and its practice in the field (Backholm and Idås 2015; Keats and Buchanan 2012). The potential of new media to diminish geographical distance thus applies also to emotional experience. Rather, personal closeness determines emotional experience in the sense that, for example, eyewitness content is more distressing when it depicts events to which a journalist can personally relate: through material things, settings, or through people she knows (Dubberley et al. 2015; Tumber 2011).

James implicitly sensed the need for preparations and training, but he did not know of any college that would attempt to prepare future journalists systematically to the experience of trauma. He had learned about the importance of coping mechanisms, but as far as he knew, these were much too often "unhealthy" (Dubberley et al. 2015) or did not solve the problem at all-such as the use of black humor, focusing on practical, mechanical aspects of the crisis, or controlling one's emotions (Buchanan and Keats 2011; Hopper and Huxford 2015; Kotišová 2017). Most importantly, he read about the key role played by media organizations and their support for their employees, which, however, was rarely well performed. Although awareness of PTSD and other psychological risks has increased among newsroom managers and journalists over the last ten years, very few media organizations have formal institutional systems to support their staff, and journalists who have mental problems are still afraid of stigmatization (Aoki et al. 2012; Clifford 2016; Dubberley et al. 2015; Keats and Buchanan 2012; see also Pedelty 1995). Were employers reluctant to 
inform journalists about potential mental health problems and help them, or did they simply lack the resources and knowledge to do so (Aoki et al. 2012)?

Still, the associations and research centers such as the Dart Centre and INSI offered not only individual training programs for those covering war zones, terrorism, and natural disasters but also evidence-based recommendations for organizations (Dubberley et al. 2015; Hight and Smyth 2003; Keats and Buchanan 2012; Sambrook 2016). On the one hand, James appreciated the attempts to de-individualize the psychological risks; he was fed up with shifting responsibility for social crisis phenomena onto the shoulders of individuals (Beck and Beck-Gernsheim 2001) and promoting biographical solutions for systematic problems (Heaphy 2007; ScheperHughes and Lock 1987). On the other hand, sentences like, "The practical tips in this booklet can help you become more effective in handling these vital areas" (Hight and Smyth 2003: 3) aroused his suspicions. He reckoned that such rhetoric, stressing (organizational) effectiveness, revealed the fact that the recommendations that were supposed to work as therapeutic tools actually worked also as a means of readapting human beings suffering trauma to the continuous state of potential war, reproducing them as subjects deployable within the next crisis event (Väliaho 2014). All the more so that there was no questioning of what the journalist saw or did.

Nevertheless, such an approach is consistent with the sensitizing understanding of emotions as culturally and socially shaped, determined and defined. The research clearly suggests that crisis reporting and crisis reporters' emotional experiences need to be studied not only in terms of personal psychological peculiarity and risk, but also as a social phenomenon and sociological problem.

Such a turn from psychology to the sociology of media-the acknowledgment and further exploration of the fact that it is the newsmaking logic and crisis context that together play a large part in shaping journalists' mental health-has already been carried out by some media researchers (mainly Glück 2016; Hopper and Huxford 2015; Jukes 2017; Pantti 2010; Richards 2007; Richards and Rees 2011). For example, Hopper and Huxford investigate how journalists, while fulfilling the ideals of objectivity, neutrality, and balance, are required to suppress their own feelings, and thus knowingly engage in emotional labor, that is, in "the management of emotion required of employees based on the demands of their job" (Hopper and Huxford 2015: 25; for a more thorough definition of 
emotional labor, see the chapter "The Emotional Experience of Crisis Reporters: The Journey"). The authors suggest that newspaper journalists both perceive the importance of keeping an emotional distance from the people and events that they cover, and experience a difficult balancing act between performing professional detachment and showing personal emotion. Correspondingly, Pantti (2010) observes that journalists reflect upon the right use of their emotions, and shift, in the course of their careers, toward greater awareness of the negative consequences of their full emotional disclosure (interestingly, while condemning the employment of "non-authentic," "artificial" emotions). In these studies, emotion management typically means developing a professional shield that brings about a specific semi-detached emotional style that has been called "autopilot," "cynicism," "right distance," or "American cool" (Backholm 2017; Hopper and Huxford 2015, 2017; Jukes 2017; Richards and Rees 2011). By comparison, Antje Glück (2016), studying British and Indian journalists, found that her interviewees unanimously consider empathy toward their sources as a central quality of their work, albeit often an invisible one. In their view, empathy can turn good journalism into great or exceptional journalism; however, the point is to know how much empathy and in which way to use it. In any case, the studies agree that journalists in general-not only crisis reporters-routinely perform emotional labor that allows them to keep the right distance from situations that they cover.

Importantly, the research suggests that the very suppression of personal, emotional identity and the reconfiguration of the self along lines of rationalism represented by journalistic objectivity (see the chapters “Articulating Journalists' Emotional Experiences of Crisis: Touching Down" and "Emotions, Technology, and Crisis Reconsidered: Ending")_doing it on autopilot, as Steven Jukes (2017) puts it - might be one factor that influences journalists' mental (ill-)health. For example, Hopper and Huxford (2015) mention that their interviewees sometimes remained troubled by incidents that happened years and even decades earlier, and were haunted by long-term guilt and even self-hatred (see also Nicolas' story from Liberia in the section "Moral Dilemmas and Guilt"). Therefore, addressing the social and sociological dimensions of crisis reporters" emotionality by dealing with the research questions listed at the beginning of this Introduction could help us understand reporters' emotions within the context of social crises and newsmaking technology. Seeing emotions as a social phenomenon and taking into account that they constitute a form of 
precarity (see e.g. Hesmondhalgh and Baker 2011) are vital for designing any institutionalized solutions.

James' memories of diverse snatches of conversations with his colleagues were starting to deluge his consciousness and were vying for his attention. For now, they resembled a chaotic whirl. Despite his short career, he had already worked in and for several European media-television, radio, newspapers, online platforms-both as an employee and as a freelancer. During that time, he talked about emotions with dozens of colleagues; rookies and old hands; men and women; "armchair" journalists making news on crises from their newsrooms; flying and roving "parachute reporters" covering crises on the spot; and permanent correspondents in conflict zones. The crises that they talked about included long-term and short-term negative events; more and less new and predictable events; and conflicts, wars, terror attacks, transportation disasters, natural disasters, environmental catastrophes, and social and economic crises that happened on five continents, with casualties ranging from individuals to hundreds of thousands.

He got up and went to the lavatory.

\section{REFERENCES}

Allan, S., et al. (Eds.). (2000). Environmental Risks and the Media. London: Routledge.

Altheide, D. (2004). Media Logic and Political Communication. Political Communication, 21(3), 293-296.

Amanpour. (2016). Syrian journalist: People 'are totally numb' to war. CNN. Retrieved from http://edition.cnn.com/videos/world/2016/11/01/intvamanpour-rami-jarrah-syria.cnn.

Andén-Papadopoulos, K., \& Pantti, M. (2013). Re-imagining Crisis Reporting: Professional Ideology of Journalists and Citizen Eyewitness Images. Journalism, 14(7), 960-977.

Aoki, Y., et al. (2012). Mental Illness Among Journalists: A Systematic Review. International Journal of Social Psychiatry, 59(4), 377-390.

Backholm, K. (2017). Distress Among Journalists Working the Incidents. In L. C. Wilson (Ed.), The Wiley Handbook of the Psychology of Mass Shootings (Wiley Clinical Psychology Handbooks) (pp. 247-263). Chichester: John Wiley \& Sons.

Backholm, K., \& Idås, T. (2015). Ethical Dilemmas, Work-related guilt, and Posttraumatic Stress Reactions of News Journalists Covering the Terror Attack in Norway in 2011. Journal of Traumatic Stress, 28, 142-148. 
Beck, U., \& Beck-Gernsheim, E. (2001). Individualization: Institutionalized Individualism and Its Social and Political Consequences. London: SAGE.

Beckett, C., \& Deuze, M. (2016). On the Role of Emotion in the Future of Journalism. Social Media + Society, 2016(3), 1-6.

Bennett, W. L., et al. (2007). When the Press Fails: Political Power and the News Media from Iraq to Katrina. Chicago: The University of Chicago Press.

Ben-Yehuda, H., et al. (2013). When Media and World Politics Meet: Crisis Press Coverage in the Arab-Israel and East-West Conflicts. Media, War and Conflict, $6(1), 71-92$.

Blaagaard, B. B. (2013). Shifting Boundaries: Objectivity, Citizen Journalism and Tomorrow's Journalists. Journalism, 14(8), 1076-1090.

Blumer, H. (1954). What Is Wrong with Social Theory? American Sociological Review, 18, 3-10.

Bowen, G. A. (2006). Grounded Theory and Sensitizing Concepts. International Journal of Qualitative Methods, 5(3), 1-8.

Buchanan, M., \& Keats, P. (2011). Coping with Traumatic Stress in Journalism: A Critical Ethnographic Study. International Journal of Psychology, 46, 127-135. https://doi.org/10.1080/00207594.2010.532799.

Carpentier, N., \& Trioen, M. (2010). The Particularity of Objectivity: A Poststructuralist and Psychoanalytical Reading of the Gap Between Objectivity-asa-value and Objectivity-as-a- practice in the 2003 Iraqi War Coverage. Journalism, 11(3), 311-328.

Christians, C. G., et al. (Eds.). (2009). Normative Theories of the Media: Journalism in Democratic Societies. Chicago: University of Illinois Press.

Clifford, L. (2016). Under Threat: The Changing State of Media Safety. International News Safety Institute. Retrieved from https://newssafety.org/ underthreat/index.html\#.

Coombs, T. W. (2010). Ongoing Crisis Communication. London: SAGE.

Cottle, S. (2009). Global Crisis Reporting: Journalism in the Global Age. Maidenhead: Open University Press.

Deuze, M. (2005). What Is Journalism? Professional Identity and Ideology of Journalists Reconsidered. Journalism, 6(4), 442-464.

Du Gay, P. (1996). Consumption and Identity at Work. London: SAGE.

Dubberley, S. et al. (2015). Making Secondary Trauma a Primary Issue: A Study of Eyewitness Media and Vicarious Trauma on the Digital Frontline. Eyewitness Media Hub. Retrieved from http://eyewitnessmediahub.com/research/vicarious-trauma.

Elias, N. (1956). Problems of Involvement and Detachment. The British Journal of Sociology, 7(3), 226-252.

Entman, R. M., et al. (2009). Doomed to Repeat: Iraq News, 2002-2007. American Behavioral Scientist, 52(5), 689-708. 
Falkheimer, J., \& Olsson, E. K. (2015). Depoliticizing Terror: The News Framing of the Terrorist Attacks in Norway, 22 July 2011. Media, War and Conflict, $8(1), 70-85$.

Feinstein, A., et al. (2015). Witnessing Images of Extreme Violence: A Psychological Study of Journalists in the Newsroom. Journal of the Royal Society of Medicine, 6(2), 1-7.

Foucault, M. (1988). Technologies of the Self. In L. H. Martin, H. Gutman, \& P. H. Hutton (Eds.), Technologies of the Self: A Seminar with Michel Foucault (pp. 16-49). London: Tavistock Publications.

Galtung, J., \& Ruge, M. B. (1965). The Structure of Foreign News. Journal of Peace Research, 2(1), 64-91.

Glück, A. (2016). What Makes a Good Journalist? Journalism Studies, $17(7), 893-903$.

Greene, R. W. (2012). Lessons from the YMCA: The Material Rhetoric of Criticism, Rhetorical Interpretation and Pastoral Power. In J. Packer \& S. B. Crofts Wiley (Eds.), Communication Matters: Materialist Approaches to Media, Mobility, and Networks (pp. 219-230). London: Routledge.

Hallin, D. C. (1986). The "Uncensored War": The Media and Vietnam. Berkeley: University of California Press.

Hansen, M. (2006). Media Theory. Theory, Culture and Society, 23(2-3), 297-306.

Harcup, T., \& O’Neill, D. (2001). What Is News? Galtung and Ruge Revisited. Journalism Studies, 2(2), 261-280.

Hay, J. (2012). The Birth of the "Neoliberal" City and Its Media. In J. Packer \& S. B. Crofts Wiley (Eds.), Communication Matters: Materialist Approaches to Media, Mobility, and Networks (pp. 121-140). London: Routledge.

Hayward, M. R., \& Tuckey, R. M. (2011). Emotions in Uniform: How Nurses Regulate Emotion at Work Via Emotional Boundaries. Human Relations, 64(11), 1501-1523.

Heaphy, B. (2007). Late Modernity and Social Change. London: Routledge.

Hesmondhalgh, D., \& Baker, S. (2011). Creative Labour: Media Work in Three Cultural Industries. London: Routledge.

Hight, J., \& Smyth, F. (2003). Tragedies and Journalists: A Guide for More Effective Coverage. Dart Center for Journalism and Trauma. Retrieved from http://dartcenter.org/sites/default/files/en_tnj_0.pdf.

Hjarvard, S. (2008). The Mediatization of Society: A Theory of the Media as Agents of Social and Cultural Change. Nordicom Review, 29(2), 105-134.

Hochschild, A. R. (1983). The Managed Heart. Berkeley: University of California Press.

Høiby, M. H., \& Ottosen, R. (2015). Journalism Under Pressure: A Mapping of Editorial Policies for Journalists Covering Conflict. Oslo: Høgskolen i Oslo og Akershus. 
Hopper, K. M., \& Huxford, J. (2015). Gathering Emotion: Examining Newspaper Journalists' Engagement in Emotional Labor. Journal of Media Practice, 16(1), 25-41.

Hopper, K. M., \& Huxford, J. (2017). Emotion Instruction in Journalism Courses: An Analysis of Introductory News Writing Textbooks. Communication Education, 66(1), 90-108.

Hoskins, A., \& O'Loughlin, B. (2010). War and Media: The Emergence of Diffused War. Cambridge: Polity Press.

Illouz, E. (2007). Cold Intimacies: The Making of Emotional Capitalism. Cambridge: Polity Press.

Joelving, F. (2010, December 17). When the News Breaks the Journalist: PTSD. Renters. Retrieved from http://www.reuters.com/article/us-ptsd-reporter/ when-the-news-breaks-the-journalist-ptsd-idUSTRE6BG3NG20101217.

Jukes, S. (2017). Affective Journalism - Uncovering the Affective Dimension of Practice in the Coverage of Traumatic News. PhD Thesis, Goldsmiths University, United Kingdom.

Keats, P. A., \& Buchanan, M. J. (2012). Covering Trauma in Canadian Journalism: Exploring the Challenges. Traumatology, 19(3), 210-222.

Knüpfer, C. B., \& Entman, R. M. (2018). Framing Conflicts in Digital and Transnational Media Environments. Media, War es Conflict, 11(4), 476-488.

Kotišová, J. (2017). Cynicism Ex Machina: The Emotionality of Reporting the 'Refugee Crisis' and Paris Terrorist Attacks in Czech Television. European Journal of Communication, 32(3), 242-256.

Lievrouw, L. A. (2014). Materiality and Media in Communication and Technology Studies: An Unfinished Project. In T. Gillespie et al. (Eds.), Media Technologies: Essays on Communication, Materiality and Society (pp. 21-52). Cambridge: The MIT Press.

Livingstone, S. (1996). On the Continuing Problems of Media Effects Research. In J. Curran \& M. Gurevitch (Eds.), Mass Media and Society (pp. 305-324). London: Edward Arnold.

Marthoz, J. P. (2017). Terrorism and the Media: A Handbook for Journalists. Paris: UNESCO.

McDonald, I. R., \& Lawrence, R. G. (2004). Filling the $24 \times 7$ News Hole: Television News Coverage Following September 11. American Behavioral Scientist, 48(3), 327-340.

Neumann, R., \& Fahmy, S. (2016). Measuring Journalistic Peace/War Performance: An Exploratory Study of Crisis Reporters' Attitudes and Perceptions. International Communication Gazette, 78(3), 223-246.

Nord, L. W., \& Strömbäck, J. (2003). Making Sense of Different Types of Crises: A Study of the Swedish Media Coverage of the Terror Attacks Against the United States and the U.S. Attacks in Afghanistan. Press/Politics, 8(4), 54-75. 
Nord, L. W., \& Strömbäck, J. (2006). Reporting More, Informing Less: A Comparison of the Swedish Media Coverage of September 11 and the Wars in Afghanistan and Iraq. Journalism, 7(1), 85-110.

Olsson, E. K., \& Nord, L. W. (2015). Paving the Way for Crisis Exploitation: The Role of Journalistic Styles and Standards. Journalism, 16(3), 341-358.

Orlikowski, W. J. (2007). Sociomaterial Practices: Exploring Technology at Work. Organization Studies, 28(9), 1435-1448.

Packer, J., \& Crofts Wiley, S. B. (2012). Introduction: The Materiality of Communication. In J. Packer \& S. B. Crofts Wiley (Eds.), Communication Matters: Materialist Approaches to Media, Mobility, and Networks (pp. 3-16). London: Routledge.

Pang, A. (2013). Social Media Hype in Times of Crises: Nature Characteristics and Impact on Organizations. Asia Pacific Media Educator, 23(2), 309-336.

Pantti, M. (2010). The Value of Emotion: An Examination of Television Journalists' Notions on Emotionality. European Journal of Communication, 25(2), 168-181.

Pauly, J. J. (2014). The New Journalism and the Struggle for Interpretation. Journalism, 15(5), 589-604.

Pedelty, M. (1995). War Stories: The Culture of Foreign Correspondents. London: Routledge.

Peters, C. (2011). Emotion Aside or Emotional Side? Crafting an 'Experience of Involvement' in the News. Journalism, 12(3), 297-316.

Reinardy, S. (2011). Newspaper Journalism in Crisis: Burnout on the Rise, Eroding Young Journalists' Career Commitment. Journalism, 12(1), 33-50.

Richards, B. (2007). Emotional Governance. Basingstoke: Palgrave Macmillan.

Richards, B., \& Rees, G. (2011). The Management of Emotion in British Journalism. Media, Culture and Society, 33(6), 851-867.

Romano, C. (1986). What? The Grisly Truth About Bare Facts. In R. K. Manhoff \& M. Schudson (Eds.), Reading the News: Pantheon guide to popular culture (pp. 38-78). New York: Pantheon.

Rosaldo, M. Z. (1984). Towards an Anthropology of Self and Feeling. In R. A. Schweder \& R. A. LeVine (Eds.), Culture Theory: Essays on Mind, Self and Emotions (pp. 137-157). Cambridge: Cambridge University Press.

Rosen, J. (2011). September 11 in the Mind of American Journalism. In B. Zelizer \& S. Allan (Eds.), Journalism after September 11 (2nd ed., pp. 35-43). London: Routledge.

Sambrook, R. (2016, April 11). Newsrooms Should Prepare to Cover Terrorist Attacks. International News Safety Institute. Retrieved from http://www. newssafety.org/news/insi-news/insi-news/detail/newsrooms-should-prepare-to-cover-terrorist-attacks-1722/.

Scheer, M. (2012). Are Emotions a Kind of Practice (And Is That What Makes Them Have a History)? A Bourdieuian Approach to Understanding Emotion. History and Theory, 51, 193-220. 
Scheper-Hughes, N., \& Lock, M. (1987). The Mindful Body: A Prolegomenon to Future Work in Medical Anthropology. Medical Anthropology Quarterly, I(1), 6-4l.

Schudson, M. (2001). The Objectivity Norm in American Journalism. Journalism, 2(2), 149-170.

Sellnow, T. L., \& Seeger, M. W. (2013). Theorizing Crisis Communication. New Jersey: John Wiley and Sons.

Shaheen, K. (2016, December 22). Covering the Last Days of Aleppo: Even from afar, the Heart Breaks. The Guardian. Retrieved from http://niemanstoryboard.org/stories/covering-the-last-days-of-aleppo-even-from-afar-theheart-breaks/.

Stearns, P. (1994). American Cool: Constructing a 20th Century Emotional Style. New York: NYU Press.

Thorsen, E. (2008). Journalistic Objectivity Redefined? Wikinews and the Neutral Point of View. New Media and Society, 10(6), 935-954.

Tumber, H. (2006). The Fear of Living Dangerously: Journalists Who Report on Conflict. International Relations, 20(4), 439-451.

Tumber, H. (2011). Reporting Under Fire: The Physical Safety and Emotional Welfare of Journalists. In B. Zelizer \& S. Allan (Eds.), Journalism After September 11 (2nd ed., pp. 319-334). London: Routledge.

Väliaho, P. (2014). Biopolitical Screens: Image, Power and the Neoliberal Brain. Cambridge: The MIT Press.

Van Der Meer, TGLA. et al. (2016). Disrupting Gatekeeping Practices: Journalists' Source Selection in Times of Crisis. Journalism. Epub ahead of print 16 May 2016. https://doi.org/10.1177/1464884916648095.

Van Leuven, S., et al. (2013). Foreign Reporting and Sourcing Practices in the Network Sphere: A Quantitative Content Analysis of the Arab Spring in Belgian News Media. New Media and Society, 17(4), 573-591.

Van Loon, J. (2002). Risk and Technological Culture: Towards a Sociology of Virulence. London: Routledge.

Van Zoonen, L. (1998). A Professional, Unreliable, Heroic Marionette (M/F): Structure, Agency and Subjectivity in Contemporary Journalisms. European Journal of Cultural Studies, 1(1), 123-143.

Vincze, H. O. (2014). 'The Crisis' as a Journalistic Frame in Romanian News Media. European Journal of Communication, 29(5), 567-582.

Vos, T. P. (2011). 'Homo Journalisticus': Journalism Education's Role in Articulating the Objectivity Norm. Journalism, 13(4), 435-449.

Wahl-Jorgensen, K. (2013). The Strategic Ritual of Emotionality: A Case Study of Pulitzer Prize- Winning Articles. Journalism, 14(1), 129-145.

Wahl-Jorgensen, K. (2016). Emotion and Journalism. In T. Witschge (Ed.). The SAGE Handbook of Digital Journalism (pp. 128-143). London: SAGE 
Publications. Epub ahead of print. Retrieved from http://orca.cf.ac. uk/87552/.

War College. (2016). The Road to Ward 17. Reuters. Retrieved from https:// soundcloud.com/war_college/the-road-to-ward-17.

Yates, D. (2016, November 15). The Road to Ward 17: My Battle with PTSD. Reuters. Retrieved from http://www.reuters.com/investigates/specialreport/ptsd-witness-yates/.

Zelizer, B., \& Allan, S. (Eds.). (2011). Journalism After September 11 (2nd ed.). London: Routledge.

Open Access This chapter is licensed under the terms of the Creative Commons Attribution 4.0 International License (http://creativecommons.org/licenses/ by $/ 4.0 /$ ), which permits use, sharing, adaptation, distribution and reproduction in any medium or format, as long as you give appropriate credit to the original author(s) and the source, provide a link to the Creative Commons licence and indicate if changes were made.

The images or other third party material in this chapter are included in the chapter's Creative Commons licence, unless indicated otherwise in a credit line to the material. If material is not included in the chapter's Creative Commons licence and your intended use is not permitted by statutory regulation or exceeds the permitted use, you will need to obtain permission directly from the copyright holder.

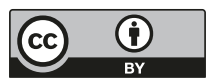

